\title{
ANALISIS KELAYAKAN EKONOMI DAN FINANSIAL PENERAPAN DISCOUNT FACTOR PADA BERBAGAI KELOMPOK BANK TERHADAP USAHATANI PADI ORGANIK DI KABUPATEN BUTON UTARA
}

\author{
Abdi $^{\left.{ }^{*}\right)}$, Mukhtar $^{1)}$, Awaluddin Hamzah $^{2)}$, La Ode Jabuddin ${ }^{1)}$ \\ ${ }^{1} J u r u s a n$ Agribisnis Fakultas Pertanian Universitas Halu Oleo Kendari Indonesia 93232 \\ ${ }^{2}$ Jurusan Penyuluhan Pertanian Fakultas Pertanian Univesritas Halu Oleo Kendari Indonesia 93232
}

*Corresponding author : cedcabdi@yahoo.com

To cite this article:

Abdi, A., Mukhtar, M., Hamzah, A., \& Jabuddin, L. (2020). Analisis Kelayakan Ekonomi dan Finansial Penerapan Discount Factor pada Berbagai Kelompok Bank terhadap Usahatani Padi Organik di Kabupaten Buton Utara. Jurnal IImiah Membangun Desa dan Pertanian, 5(4), 129 - 139. doi:http://dx.doi.org/10.37149/jimdp.v5i4.13040

Received: July 22, 2020; Accepted: August 12, 2020; Published: August 31, 2020

\section{ABSTRACT}

Organic food agriculture, especially rice, is a potential business opportunity in the present and in the future. This is based on the principle of the benefits of organic food, which puts forward the principles of good health for plants, soil, animals, earth, and humans as an interconnected and inseparable whole. The objectives of this study were to analyze the economic and financial feasibility of organic rice farming in North Buton Regency, to analyze the economic and financial viability of farming when input prices change, and to compare the feasibility of organic rice farming in various bank groups. The data used in this study are primary and secondary data, the variable coverage of which consists of the amount of organic rice production, production price, and the components of farm costs. Respondents were determined using accidental sampling technique, in order to obtain 60 farmer household respondents. Furthermore, an economic and financial feasibility analysis approach is used which consists of 3 criteria, namely net present value, net benefit-cost ratio, and internal rate of return. The results showed that: (1) organic rice farming in North Buton Regency based on economic and financial feasibility criteria is feasible to be cultivated and or developed, (2) Even though there has been a change in input prices, organic rice farming in Buton Utarata Regency is feasible to be cultivated and or developed, (3) the selection of business investment credit in the stateowned bank group and the national private bank group is more feasible to operate, while the business investment credit in the regional government bank group is vulnerable to the risk of loss. Therefore, in applying for investment credit for organic rice farming, farmers must choose a financial institution in the state bank group or national private bank.

Keywords : bank group; economic and financial feasibility; organic rice farming

\section{PENDAHULUAN}

Bahan pangan beras masih merupakan komoditas strategis bagi perekonomian nasional di sebagian besar negara-negara berkembang (Rusastra et al., 2016). Kondisi ini juga terjadi secara Nasional dan secara khusus juga terjadi di seluruh kabupaten/kota di Indonesia. Usaha pertanian pangan organik khusunya tanaman padi, merupakan peluang bisnis potensil di masa kini dan akan datang (Sari et al., 2019). Hal ini didasarkan pada asas manfaat pangan organik, yang lebih mengedepankan prinsip kesehatan baik terhadap tanaman, tanah, hewan, bumi dan manusia sebagai satu kesatuan yang saling berhubungan dan tidak terpisahkan (Mayrowani, 2016). Selain itu, sistem pertanian organik juga berorientasi terhadap penghapusan aplikasi penggunaan pupuk kimia dalam proses budidaya, karena diperkirakan pertumbuhan pasar dan permintaan produk ini dapat mencapai 20-30\% setiap tahunnya (Sari \& Fahmi, 2018). Hal ini dipicu oleh semakin sadarnya masyarakat sebagai konsumen dalam mengkonsumsi produk organik.

Usahatani padi organik telah sejak lama diterapkan di Kabupaten Buton Utara dan masih tetap ada hingga saat ini.Hal ini disebabkan karena sistem pertanian organik merupakan warisan 
tradisional, yang secara turun temurun diwariskan pada setiap generasi. Bahkan di daerah lain seperti Desa Mangesta Kabupaten Tabanan, sistem pertanian padi organik dijadikan sebagai potensi objek agrowisata, karena pengelolaan usahataninya mulai dari pembukaan lahan hingga panen dilakukan secara manual dan tradisional (Herawati, 2015). Begitupula halnya di Kabupaten Buton Utara proses pembukaan lahan hingga panen juga dilakukan secara tradisional, tidak menerapkan penggunaan teknologi seperti herbisida, pestisida dan penggunaan pupuk kimia. Hal ini dilakukan agar eksistensi kearifan lokal tetap terjaga, terutama dalam hal kualitas produksi seperti warna, aroma dan tekstur padi. Fenomena inilah yang menjadi pembeda dan merupakan ciri khas tersendiri bagi daerah dalam persaingan produk di pasaran.

Produksi beras organik Kabupaten Buton Utara telah mampu bersaing di pasaran global. Hal ini ditandai dengan adanya permintaan sampai ke luar daerah, karena varietas padi organik yang dikembangkan mempunyai segmentasi pasar yang khusus. Bahkan pemerintah daerah sendiri telah gencar melakukan promosi beras organik sebagai hasil produksi pertanian unggulan yang sementara dikembangkan hingga ke luar negeri, seperti di Belanda, Jerman dan beberapa negara di Timur Tengah. Selain itu, pemerintah pusat melalui Kementerian Pertanian Republik Indonesia juga telah membantu mempromosikan produk ini hingga ke Korea Selatan. Segmen pasar komoditas padi organik secara global dapat menciptakan peluang dalam peningkatan pendapatan dan daya saing (Tudisca et al., 2014). Di pasar global khususnya pada negara-negara Uni Eropa, pertanian organik sangat dihargai oleh konsumen. Hal ini disebabkan karena beberapa hal: (1) menganggap produk organik memiliki berkualitas lebih tinggi, (2) kurangnya bahan kimia yang digunakan selama proses produksi, (3) sebagian besar tenaga kerja dilakukan oleh petani konvensional (Sgroi et al., 2015)

Potensi pengembangan usahatani padi organik di Kabupaten Buton Utara cukup potensial. Hal ini dapat dilihat dari aspek produktivitas, yakni kemampaun suatu lahan dalam menghsilkan produksi per sataun hektar. Pada tahun 2013 produktivitas usahatani padi ladang/organik di Kabupaten Buton Utara sebesar 2,97 ton/hektar dan mengalami peningkatan di tahun 2014 menjadi 3,12 ton/ha. Pada tahun 2016 merupakan waktu dimana tercapainya produktivitas usahatani tertinggi, yakni sebesar 3,90 ton/hektar (BPS, 2018.a). Selain itu dari aspek pertumbuhan produktivitas, menunjukkan bahwa dalam rentang waktu lima tahun (2013-2017) produktivitas usahatani padi ladang mengalami pertumbuhan positif hingga mencapai $2,16 \%$, sedangkan produktivitas padi sawah menurun sebesar $0,01 \%$. Fenomena tersebut menunjukkan bahwa dari aspek produktivitas, usaha pengembagan padi ladang atau padi organik di Kabupaten Buton Utara memiliki potensi yang memadai (Hamzah et al., 2019).

Di sisi lain, pengembangan usahatani padi organik memiliki beberapa kendala baik dari aspek internal petani maupun dari aspek eksternal petani. Seperti halnya petani lainnya di Indonesia, karakteristik petani padi organik di Kabupaten Buton Utara juga memiliki kendala dari aspek kualitas sumberdaya manusia maupun kepemilikkan modal usaha. Kualitas sumberdaya manusia dapat diproksi berdasarkan tingkat pendidikan, dimana dengan adanya pendidikan dapat menambah pengetahuan dan mengubah pola pikir (Listiana et al., 2018). Apabila petani memiliki pendidikan yang memadai, maka petani tersebut cenderung lebih muda berpikir dan bertindak secara rasional dalam mengambil suatu keputusan dengan mempertimbangkan berbagai aspek yang akan terjadi. Hamzah et al., (2018) melaporkan bahwa rata-rata tingkat pendidikan formal yang pernah dilalui petani padi organik di Kabupaten Buton adalah tidak tamat SMP (8,67 tahun). Kondisi ini menunjukkan bahwa rata-rata petani padi organik memiliki tingkat pendidikan yang kurang memadai. Hal tersebut tentunya akan mempengaruhi cara kerja dan pola pikir petani dalam mengelola usahataninya. Hasil penelitian (Sari et al., 2019) menemukan bahwa tingkat pendidikan petani memiliki pengaruh yang signifikan terhadap peningkatan produksi padi organik di Kabupaten Sleman.

Dari aspek kepemilikan modal usaha, petani padi organik di Kabupaten Buton Utara secara umum tidak memiliki biaya yang cukup dalam mengolah usahataninya secara berkesinambungan. Biaya investasi pengadaan pagar dan biaya operasional tenaga kerja merupakan komponen biaya terbesar dalam proses produksi. Rata-rata biaya produksi yang diperhitungkan pada usahatani padi organik lebih tinggi dari pada padi anorganik per usahatani maupun perhektar (Rahayu dan Yuliawati, 2020). Namun dari aspek kelayakan usaha, komoditi padi organik mampu memberikan keuntungan yang cukup besar bagi petani dalam hal ini secara finansial layak diusahakan (Aminah, 2017).

Olehnya itu aksesbilitas lembaga perbankan atau lembaga keuangan lainnya merupakan salah satu alternatif yang dapat ditempuh petani dalam rangka pemenuhan kebutuhan modal usaha.Petani dapat memilih secara bebas jenis atau kelompok bank dengan imbalan jasa lunak, dengan berbagai pilihan waktu pengembalian. Peran pemerintah daerah dibutuhkan dalam memfasilitasi petani untukmengakses modal usaha, dengan alternatif jaminan yang tidak memberatkan petani. Berdasarkan fenomena tesebut, maka yang menjadi tujuan dalam penelitian ini adalah untuk menganalisis kelayakan ekonomi dan finansial usahatani padi organik di Kabupaten 
Buton Utara, menganalisis kelayakan ekonomi dan finansial usahatani jika terjadi perubahan harga input, dan membandingkan kelayakan usahatani padi organik pada berbagai kelompok bank.

\section{MATERI DAN METODE}

Penelitian ini dilaksanakan pada tahun 2018 di Kabupaten Buton Utara, dengan pertimbangan bahwa wilayah tersebut merupakan daerah sentra produksi pengembangan padi organik. Agar memudahkan peneliti, penentuan responden dilakukan dengan teknik sampling accidental, yakni memilih responden yang dianggap cocok dengan karakteristik sampel (Rianse \& Abdi, 2008; Sugiyono, 2012), sehingga diperoleh sebanyak 60 responden rumah tangga. Jenis data dalam penelitian ini berupa data primer dan sekunder, yang cakupan variabelnya terdiri dari jumlah produksi padi oganik, harga produksi dan komponen-komponen biaya usahatani. Data primer dalam penelitian ini bersumber dari rumah tangga petani padi organik dalam hal ini kepala keluarga, sedangkan data sekunder bersumber dari Badan Pusat Statistik (BPS) Daerah Kabupaten Buton Utara. Selanjutnya untuk menjawab tujuan penelitian ini, digunakan pendekatan analisis kelayakan ekonomi dan finansial. Analisis tersebut terdiri dari 3 kriteria, yaitu net present value (NPV), net benefit cost ratio $($ Net $B / C)$ dan internal rate of return $(I R R)$. Dalam penelitian ini, model kriteria kelayakan ekonomi dan finansial usahatani padi organik mengacu pada hasil penelitian Abdi (2014); Neliyana et al., (2016) dan Sgroi et. al. (2015) dengan persamaan sebagai berikut:

Dimana;

$$
N P V=\sum_{t=1}^{n} \frac{(B t-C t)}{(1+i)^{t}}
$$

$\mathrm{NPV}=$ Net present value

$\mathrm{B}_{\mathrm{t}}=$ Benefit pada tahun ke- $\mathrm{t}$

$\mathrm{C}_{\mathrm{t}}=$ Biaya yang dikeluarkan pada tahun $\mathrm{t}$

$\mathrm{t}=$ Tahun berlakunya investasi

$\mathrm{n}=$ Umur ekonomis peralatan

$\mathrm{i}=$ Suku bunga yang berlaku

Kriteria pengambilan keputusan;

$$
N e t \frac{B}{C}=\frac{\sum_{t=1}^{n} N P V(+)}{\sum_{t=1}^{n} N P V(-)}
$$

Jika nilai Net $B / C>1$, berarti investasi layak

Jika nilai Net $B / C<1$, berarti investasi tidak layak

Jika nilai Net $B / C=1$, berarti investasi pulang pokok

Kriteria pengambilan keputusan;

$$
I R R=i_{1}+\left(\frac{N P V 1}{N P V 1-N P V 2}\right)\left(i_{2}-i_{1}\right.
$$

Jika nilai IRR > bunga bank, berarti investasi layak

Jika nilai IRR < bunga bank, berarti investasi tidak layak

Jika nilai IRR = bunga bank, berarti pulang pokok

\section{HASIL DAN PEMBAHASAN}

\section{Harga dan Jumlah Produksi Padi Organik}

Harga merupakan salah satu faktor yang dapat menentukan besarnya jumlah penerimaan dan pendapatan petani (Yasa \& Handayani, 2017). Dalam penelitian ini diperoleh informasi bahwa harga

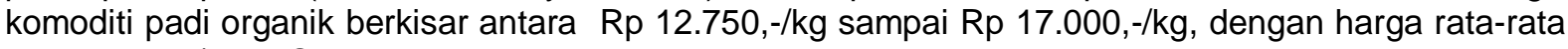
Rp $14.875,-/ \mathrm{kg}$. Sementara itu, produksi yang dimaksud adalah hasil akhir dari usahatani padi organik dalam bentuk beras dalam satuan kilogram per tahun $(\mathrm{kg} / \mathrm{thn})$. Dalam luasan lahan 1 hektar, setiap petani dapat menghasilkan produksi sebanyak 100-120 kopo. Kopo merupakan istilah lokal yang digunakan petani yakni kumpulan hasil panen yang terdiri dari beberapa ikatan besar, biasanya 7 - 8 ikatan kecil. Satu ikatan besar (1 kopo) memiliki volume 20 liter sampai 25 liter beras.

Tabel 1. Harga dan produksi padi organik di Kabupaten Buton Utara

\begin{tabular}{ccc}
\hline Uraian & Harga $(\mathrm{Rp} / \mathrm{Kg})$ & Produksi $(\mathrm{Ton} / \mathrm{Ha})$ \\
\hline Tertinggi & 17.000 & 2,4 \\
Terendah & 12.750 & 1 \\
Rata-Rata & 14.875 & 1,7 \\
\hline
\end{tabular}


Tabel 1 menunjukkan bahwa jumlah produksi tertinggi yang diperoleh petani respoden padi organik di Kabupaten Buton Utara sebesar 2,4 ton/ha dan terendah sebesar 1 ton/ha dengan ratarata produksi sebesar 1,7 ton/ha/thn. Bervariasinya jumlah produksi ini dapat disebabkan karena perbedaan penggunaan input oleh masing-masing petani, seperti luas lahan, perlakuan terhadap tanaman, dan penggunaan teknologi, serta varietas benih yang digunakan.Sistem budidaya padi organik multikultur memerlukan perawatan intensif, sehingga membuat komponen biaya menjadi tinggi dibandingkan budidaya padi secara konvensional (Machmuddin et al., 2017).

\section{Biaya Produksi Usahatani Padi Organik Biaya Investasi}

Investasi merupakan kegiatan untuk menanamkan sejumlah modal dalam suatu bisnis dengan tujuan memperoleh pendapatan setelah jangka waktu tertentu (Padangaran, 2013). Hasil penelitian menunjukkan bahwa total biaya investasi pada usahatani padi organik di Kabupaten Buton Utara bervariasi, yakni berkisar antara Rp 6.400.000,- sampai Rp 18.750.000,- dengan biaya rata-rata investasi sebesar Rp 12.575.000,- per hektar. Biaya investasi terbesar terletak pada alokasi pembukaan lahan yakni sebesar Rp 3.500.000,- sampai Rp 10.000.000,- dengan biaya rata-rata sebesar Rp 6.750.000,- per hektar. Sementara itu, biaya investasi pagar berjumlah Rp 1.200.000,sampai Rp 6.000.000,- dengan rata-rata sebesar Rp 3.600.000,- per hektar. Hasil penelitian juga menunjukkan bahwa untuk biaya investasi jaring/waring berkisar antara Rp 1.200.000,- sampai $\mathrm{Rp} 2.000 .000$,- dengan biaya rata-rata sebesar $\mathrm{Rp} 1.600 .000$,- per hektar.

Tabel 2. Rata-rata biaya investasi usahatani padi organik di Kabupaten Buton Utara

\begin{tabular}{crrr}
\hline \multirow{2}{*}{ Jenis Biaya Investasi } & \multicolumn{3}{c}{ Nilai (Rp/Ha) } \\
\cline { 2 - 4 } & Tertinggi & Terendah & Rata-Rata \\
\hline Pembukaan Lahan & 10.000 .000 & 3.500 .000 & 3.750 .000 \\
Pagar & 6.000 .000 & 1.200 .000 & 1.600 .000 \\
Jaring/Waring & 2.000 .000 & 1.200 .000 & 625.000 \\
Pondok Jaga & 750.000 & 500.000 & 12.575 .000 \\
\hline Total & 18.750 .000 & 6.400 .000 & \\
\hline
\end{tabular}

Selain itu, pada Tabel 2 juga diperoleh informasi bahwa biaya investasi terkecil berada biaya pengadaan pondok kerja, yakni berisar antara $R p 500.000$,- sampai $R p 750.000$,- dengan rata-rata sebesar Rp 625.000,- per hektar. Besar kecilnya investasi yang telah dikeluarkan oleh petani padi organik di Kabupaten Buton Utara, diharapkan akan berdampak terhadap peningkatan jumlah produksi yang akan diperoleh pada masa-masa yang akan datang. Artinya, pengadaan atau pembelanjaan investasi tersebut akan meningkatkan kapasitas memproduksi (manfaat ekonomi) dalam jangka panjang.

\section{Biaya Tidak Tetap dan Biaya Tetap}

Hasil penelitian menunjukkan bahwa total biaya tidak tetap pada usahatani padi organik di Kabupaten Buton Utara bervariasi, yakni berkisar antara Rp 9.425.000,- sampai Rp 21.540.000,dengan biaya rata-rata sebesar Rp 15.482.000,- per hektar. Biaya tidak tetap terbesar terletak pada alokasi biaya panen yakni berkisar antara $\mathrm{Rp} 3.825 .000$,- sampai $\mathrm{Rp} 12.240 .000$,- dengan rata-rata sebesar Rp 8.032.000,- per hektar. Sementara itu, biaya terendah yang di alokasikan pada biaya tidak tetap adalah biaya pengadaan pupuk organik yakni berkisar antara $R p$ 100.000,- sampai Rp 400.000,- dengan rata-rata sebesar Rp 250.000,- per hektar.

Tabel 3. Rata-rata biaya tidak tetap usahatani padi organik di Kabupaten Buton Utara

\begin{tabular}{crrr}
\hline \multirow{2}{*}{ Jenis Biaya Tidak Tetap } & \multicolumn{3}{c}{ Nilai (Rp/Ha) } \\
\cline { 2 - 4 } & Tertinggi & Terendah & Rata-Rata \\
\hline Benih & 500.000 & 500.000 & 500,000 \\
Pupuk Organik & 400.000 & 100.000 & 250,000 \\
Biaya Tanam & 1.500 .000 & 1.000 .000 & $1,250,000$ \\
Pemeliharaan & 6.200 .000 & 3.500 .000 & $4,850,000$ \\
Panen & 12.240 .000 & 3.825 .000 & $8,032,500$ \\
Lain-Lain & 700.000 & 500.000 & 600,000 \\
\hline Total & 21.540 .000 & 9.425 .000 & 15.482 .500 \\
\hline
\end{tabular}


Rendahnya pengeluaran pada biaya pengadaan pupuk organik di Kabupaten Buton Utara dikarenakan secara kuantitas penggunaannya juga relatif kecil.Kondisi ini dipicuh oleh stigma masyarakat yang secara turun-temurun tidak mengaplikasikan penggunaan pupuk dalam setiap kegiatan usahatani, sehingga keseimbangan lingkungan dan keorginalan produksi padi tetap terjaga. Berbeda dengan usahatani padi sawah atau petani padi anorganik, dimana pengadaan pupuk merupakan komponen biaya yang cukup signifikan dalam berproduksi (Mamondol, 2016; Nurjayanti et al., 2016). Selanjutnya, rata-rata biaya tetap yang dikeluarkan oleh petani padi organik dalam penelitian ini disajikan pada Tabel 4.

Tabel 4. Rata-rata biaya tetap usahatani padi organik di Kabupaten Buton Utara

\begin{tabular}{crrr}
\hline Jenis Biaya Tetap & \multicolumn{3}{c}{ Nilai $(\mathrm{Rp} / \mathrm{Ha})$} \\
\cline { 2 - 4 } & Tertinggi & Terendah & Rata-Rata \\
\hline Peralatan & $1,260,000$ & 945,000 & $1,102,500$ \\
Pajak Lahan & 24,600 & 18,000 & 21,300 \\
\hline Total & $1,284,600$ & 963,000 & $1,123,800$ \\
\hline
\end{tabular}

Tabel 4 menunjukkan bahwa terdapat 2 (dua) jenis biaya tetap yang dikeluarkan per hektar oleh petani padi organik di Kabupaten Buton Utara, yakni biaya peralatan dan biaya pajak lahan. Hasil penelitian menunjukkan bahwa rata-rata nilai biaya tetap tertinggi terletak pada pengadaan peralatan. Dalam penelitian ini, jenis peralatan yang digunakan petani padi organik di Kabupaten Buton Utara terdiri dari: parang/sabit, cangkul, linggis, kampak, sprayer, dan penumbuk padi. Hasil penelitian menunjukkan bahwa besarnya biaya tetap usahatani padi organik berkisar antara $\mathrm{Rp}$ 963.000,- sampai Rp 1.284.600,- dengan rata-rata biaya tetap sebesar Rp 1.123.800,- per hektar. Nilai tersebut lebih rendah jika dibandingkan dengan usahatani jagung, dimana rata-rata biaya tetapnya hanya sebesar Rp 207.166,- per hektar (Fadlun et al., 2017). Berdasarkan perhitungan rata-rata total biaya usaha tani padi organik di Kabupaten Buton Utara diperoleh sebesar Rp 16.606.300,-, dimana nilai ini lebih rendah dibandingkan dengan hasil penelitian yang dilakukan oleh (Suswadi, 2018) di Kabupaten Boyolali yakni sebesar Rp 20.495.000,-.

\section{Analisis Manfaat dan Biaya Ekonomi UsahataniPadi organik Analisis Kelayakan Ekonomi dan Finansial}

Asumsi dasar yang digunakan dalam perhitungan analisis kelayakan ekonomi dan finansial usahatani padi organik di Kabupaten Buton Utara adalah sebagai berikut:

- Usaha padi organik dilakukan oleh masyarakat tani.

- Seluruh sarana dan prasarana yang digunakan pada usahatanipadi organik dianggap baru.

- Harga produksi dan sarana produksi pada usahatanipadi organik yang digunakan berdasarkan pada asumsi harga di tingkat petani.

- Umur proyek ditentukan selama 5 tahun.

- Umur ekonomis dari sarana (barang investasi) dan peralatan rata-rata4 tahun.

- Penerimaan/manfaat dan biaya produksi selama umur proyek dianggap tetap.

- Tingkat suku bunga (discount factor) yang digunakan adalah rata-rata suku bunga kredit investasi yang belaku tahun 2018, pada kelompok bank persero yaitu sebesar $10,24 \%$, kelompok bank pemerintah daerah sebesar $11,41 \%$, dan kelompok bank swasta nasional sebesar 10,77\% (BPS, 2018.b).

Berdasarkan asumsi tersebut selanjutnya perhitungan diproyeksikan setiap tahun, mulai dari pengadaan peralatan modal investasi sampai kegiatan penjualan hasil produksi. Petani padi organik akan mulai memperoleh keuntungan pada tahun ke-1. Selanjutnya kriteria penilaian kelayakan finansial/investasi pada usahatani padi organik dalam penelitian ini terdiri dari net present value (NPV), net benefit cost ratio (Net $B / C)$, daninternal rate of return (IRR). Ringkasan hasil analisis ekonomi dan finansial pada usahatanipadi organikdisajikan dalam Tabel 5.

Tabel 5. Analisis ekonomi dan finansial usahatani padi organik

\begin{tabular}{cccc}
\hline $\begin{array}{c}\text { Indikator dan Kriteria } \\
\text { Kelayakan }\end{array}$ & $\begin{array}{c}\text { Kelompok Bank } \\
\text { Persero (df 10,24\%) }\end{array}$ & $\begin{array}{c}\text { Kelompok Bank Pemerintah } \\
\text { Daerah (df 10,90\%) }\end{array}$ & $\begin{array}{c}\text { Kelompok Bank } \\
\text { Swasa Nasional (df } \\
10,77 \%)\end{array}$ \\
\hline NPV (Layak) & 19.534 .147 & 18.627 .852 & 19.118 .329 \\
Net B/C (Layak) & 2,55 & 2,48 & 2,52 \\
IRR (Layak) & 63,91 & 63,91 & 63,91 \\
\hline
\end{tabular}


Hasil analisis menunjukkan bahwa besarnya nilai NPV pada discount factor 10,24\%; 10,90\%; dan $10,77 \%$ pada usahtani padi organik di Kabupaten Buton Utara layak untuk dikembangkan, karena dari setiap nilai $N P V>0$. Hasil analisis juga menunjukkan bahwa pada kelompok bank persero mempunyai nilai NVP yang lebih besar dari pada kelompok bank pemerintah daerah ataupun kelompok bank swasta nasional yaitu sebesar Rp 19.534.147,-. Sementara itu, nilai NPV usahatani padi organik pada kelompok bank pemerintah daerah dan kelompok bank swasta nasional, masingmasing sebesar Rp 18.627.852,- dan Rp 19.118.329,-. Selanjutnya, analisis Net B/C menunjukkan bahwa pada masing-masing tingkat diskonto nilai Net $B / C$ lebih besar dari 1 (Net B/C > 1). Pada kelompok bankpersero, nilai Net $B / C$ lebih besar dari pada kelompok bank pemerintah daerah ataupun kelompok bank swasta nasional yaitu sebesar 2,55, sedangkan pada kelompok bank pemerintah daerah dan kelompok bank swasta nasional masing-masing sebesar 2,48 dan 2,52. Nilai tersebut memberikan makna bahwa setiap pengeluaran sebesar $\mathrm{Rp} 1,-$ akan menyebabkan kenaikan pendapatan bersih sebesar 2,55; 2,48; dan 2,52 kali lipat, sehinggan dapat dikatakan bahwa usahatani padi organik di Kabupaten Buton Utara dari aspek Net B/C layak untuk dikembangkan. Dari perhitungan secara interpolasi, hasil analisis menunjukkan bahwa nilai pada discount factor 10,24\%; 10,90\%; dan 10,77\% pada usahatani padi organik di Kabupaten Buton Utara juga layak untuk dikembangkan. Hal ini dapat dilihat dari setiap nilai $I R R$ yang menunjukkan angka yang lebih besar dari tingkat diskonto (IRR $>$ df), baik tingkat diskonto yang berlaku pada kelompok bank persero, kelompok bank pemerintah daerah, maupun pada kelompok bank swasta nasional yakni sebesar $63,91 \%$.

Berdasarkan fenomena tersebut dapat disimpulkan bahwa secara ekonomi dan finansial usaha padi organik di Kabupaten Buton Utara layak untuk diusahakan dan atau dikembangkan. Fakta tersebut ditunjukkan oleh nilai $N P V>0, N e t B / C>1$, dan nilai $I R R>i$ (tingkat diskonto). Hasil penelitian ini relevan dengan hasil penelitian Krisdianto et al., (2014), dimana hasil analisis berdasarkan kriteria $N P V$, Net $B / C$, IRR dan analisis sensitivitas menunjukkan bahwa usahatani padi organik oleh kelompok tani KNOC di Kabupaten Ngawi layak untuk diusahakan. Sementara itu, dari aspek manfaat ekonomi ( $R / C$ rasio) menunjukkan bahwa usahatani padi organik lebih efisien dibandingkan dengan usahatani konvensioal (Jamil et al., 2018; Kurniawan, (2016).

\section{Analisis Sensitivitas}

Analisis kepekaan (sensitivitas) dalam penelitian ini mengacu pada hasil penelitian yang pernah dilakukan oleh Abdi (2014), yakni menggunakan pendekatan pengaruh inflasi terhadap tingkat kelayakan finansial. Pada analisis ini disusun dalam 3 (tiga) skenario, yakni (a) manfaat tetap dan biaya naik $10 \%$, (b) manfaat turun $10 \%$ dan biaya tetap, serta (c) manfaat turun $10 \%$ dan biaya naik $10 \%$. Penetapan inflasi sebesar $10 \%$ merupakan angka di atas rata-rata laju inflasi tertinggi yang terjadi baik di Sulawesi Tenggara (Kabuapten Buton Utara) maupun secara nasional selama kurun waktu tahun 2014-2018. Hal ini dilakukan untuk mengantisipasi adanya ketidakpastian terutama dari segi perubahan harga-harga input, sehingga penulsi menetapkan nilia $10 \%$ sebagai dasar perhitungan simulasi finansial.

\section{Skenario Pertama (Manfaat Tetap dan Biaya Naik 10\%)}

Kenaikan harga faktor produksi (input) sebesar $10 \%$ akan menyebabkan terjadinya kenaikan biaya pada usahatanipadi organik yang dikelola petani. Kenaikan biaya-biaya tersebut dijabarkan sebagai berikut:

- Kenaikan harga sebesar $10 \%$ maka menyebabkan kenaikan rata-rata biaya investasi sebesar Rp 13.832.500,- pada tahun awal usaha.

- Khusus pada tahun ke-4 terjadi penambahan biaya Rp 5.126.000,-, dimana pada tahun ini terdapat penambahan biaya pagar, jaring/waring, dan biaya pondok jaga. Hal ini disebabkan karena umur ekonomis barang tersebut selama 4 (empat) tahun.

Berdasarkan perubahan-perubahan biaya akibat adanya inflasi sebesar $10 \%$, maka hasil analisis sensitivitas usaha padi organik, dapat dilihat pada Tabel 6 .

Tabel 6. Analisis ekonomi dan finansial usahatani padi organik dengan manfaat tetap dan biaya naik $10 \%$

\begin{tabular}{cccc}
\hline $\begin{array}{c}\text { Indikator dan Kriteria } \\
\text { Kelayakan }\end{array}$ & $\begin{array}{c}\text { Kelompok Bank } \\
\text { Persero } \\
\text { (df 10,24\%) }\end{array}$ & $\begin{array}{c}\text { Kelompok Bank } \\
\text { Pemerintah Daerah } \\
\text { (df 10,90\%) }\end{array}$ & $\begin{array}{c}\text { Kelompok Bank } \\
\text { Swasa Nasional } \\
\text { (df 10,77\%) }\end{array}$ \\
\hline NPV (Layak) & 11.960 .095 & 11.240 .235 & $11.629, .836$ \\
Net B/C (Layak) & 1,86 & 1,81 & 1,84 \\
IRR (Layak) & 42,10 & 42,10 & 42,10 \\
\hline
\end{tabular}


Berdasarkan hasil analisis diketahui bahwa walaupun terjadi kenaikan biaya sebesar $10 \%$, usahatani padi organik yang dikelola petani masih layak untuk diusahakan dan atau dikembangkan. Pada kelompok bank persero, nilai NVP lebih besar dari pada kelompok bank pemerintah daerah ataupun kelompok bank swasta nasional yaitu sebesar Rp 11.960.095,-. Sementara itu, nilai NPV usahatani padi organik pada kelompok bank pemerintah daerah dan kelompok bank swasta nasional, masing-masing sebesar Rp 11.240.235,- dan Rp 11.629,.836,-. Tabel 6 juga menunjukkan bahwa pada kelompok bank persero juga mempunyai nilai Net $B / C$ yang lebih besar dari pada kelompok bank pemerintah daerah ataupun kelompok bank swasta nasional yaitu sebesar 1,86 . Selain itu, nilai Net $B / C$ usahatani padi organik pada kelompok bank pemerintah daerah dan kelompok bank swasta nasional, masing-masing sebesar 1,81 dan 1,84. Nilai tersebut memberikan makna bahwa setiap pengeluaran sebesar $\mathrm{Rp} 1$,- akan menyebabkan kenaikan pendapatan bersih sebesar 1,86; 1,81; dan 1,84 kali lipat. Olehnya itu dari segi nilai $\mathrm{Net} B / C R$, usahatani padi organik di Kabupaten Buton Utara juga layak untuk dikembangkan.

Selanjutnya, dari perhitungan secara interpolasi dengan biaya naik $10 \%$, menunjukkan bahwa nilai pada discount factor 10,24\%; 10,90\%; dan 10,77\% pada usahatani padi organik di Kabupaten Buton Utara masih layak untuk dikembangkan. Hal ini dapat dilihat dari setiap nilai IRR yang menunjukkan angka yang lebih besar dari tingkat diskonto $(I R R>d f)$, baik tingkat diskonto yang berlaku pada kelompok bank persero, kelompok bank pemerintah daerah, maupun pada kelompok bank swasta nasional yakni sebesar $42,10 \%$. Kondisi tersebut menunjukkan bahwa usahatani padi organik di Kabupaten Buton Utara tidak sensitif atau tidak peka terhadap perubahan harga. Hal ini sejalan dengan hasil penelitian Sahara (2007) yang menunjukkan bahwa usahatani padi sawah di Kabupaten Konawe juga tidak sensitif terhadap perubahan harga-harga input.

\section{Skenario Kedua (Manfaat Turun 10\% dan Biaya Tetap)}

Penurunan manfaat sebesar $10 \%$ pada usahatani padi organik di Kabupaten Buton Utara, akan menyebabkan penurunan rata-rata manfaat atau penerimaaan dari Rp 25.287.500,- menjadi Rp 22.758.750,- per hektar per tahun. Penurunan manfat tersebut dapat disebabkan karena penurunan harga produksi dari rata-rata sebesar $\mathrm{Rp} \mathrm{14.875,-/kg}$ (harga aktual) menjadi rata-rata sebesar Rp 13.388/kg (harga simulasi). Hasil analisis menunjukkan bahwa dengan terjadinya penurunan manfaat sebesar $10 \%$ dan biaya tetap, maka usahatanipadi organik tetap layak untuk diusahakan dan atau dikembangkan. Kelayakan tersebut didasarkan pada nilai kriteria investasi yang diperoleh yaitu $N P V>0, N e t B / C>1$, dan $I R R>i$ (tingkat diskonto).

Tabel 7. Analisis ekonomi dan finansial usahatani padi organik dengan manfaat turun $10 \%$ dan biaya tetap

\begin{tabular}{cccc}
\hline $\begin{array}{c}\text { Indikator dan Kriteria } \\
\text { Kelayakan }\end{array}$ & $\begin{array}{c}\text { Kelompok Bank } \\
\text { Persero } \\
\text { (df 10,24\%) }\end{array}$ & $\begin{array}{c}\text { Kelompok Bank } \\
\text { Pemerintah Daerah } \\
\text { (df 10,90\%) }\end{array}$ & $\begin{array}{c}\text { Kelompok Bank } \\
\text { Swasa Nasional } \\
\text { (df 10,77\%) }\end{array}$ \\
\hline NPV (Layak) & 10.006 .680 & 9.377 .450 & 9.718 .003 \\
Net B/C (Layak) & 1,80 & 1,75 & 1,77 \\
IRR (Layak) & 39,80 & 39,80 & 39,80 \\
\hline
\end{tabular}

Tabel 7 menunjukkan bahwa pada kelompok bank persero, nilai NVP juga lebih besar dari pada kelompok bank pemerintah daerah ataupun kelompok bank swasta nasional yakni sebesar Rp 10.006.680,-, sedangkan pada kelompok bank pemerintah daerah dan kelompok bank swasta nasional masing-masing sebesar $R p$ 9.377.450,- dan $R p$ 9.718.003,-. Selain itu, hasil penelitian juga menunjukkan bahwa pada kelompok bank persero juga mempunyai nilai $N e t B / C$ yang lebih besar dari pada kelompok bank pemerintah daerah ataupun kelompok bank swasta nasional yaitu sebesar 1,80, sedangkan pada kelompok bank pemerintah daerah dan kelompok bank swasta nasional, masing-masing sebesar 1,75 dan 1,77. Nilai tersebut memberikan makna bahwa setiap pengeluaran sebesar Rp 1,- akan menyebabkan kenaikan pendapatan bersih sebesar 1,80; 1,75; dan 1,77 kali lipat (Net $B / C R>1$ ), yang berarti bahwa usahatani padi organik tetap layak untuk dikembangkan. Selanjutnya, dari perhitungan secara interpolasi dengan manfaat/ penerimaan turun sebesar 10\%, menunjukkan bahwa nilai pada discount factor 10,24\%; 10,90\%; dan 10,77\%, usahatani padi organik juga masih layak untuk dikembangkan. Hal ini dapat dilihat dari setiap nilai IRR yang menunjukkan angka yang lebih besar dari tingkat diskonto $(I R R>d f)$, baik tingkat diskonto yang berlaku pada kelompok bankpersero, kelompok bank pemerintah daerah, maupun pada kelompok bank swasta nasional yakni sebesar $39,80 \%$. Kondisi ini juga berlaku dan relevan dengan komoditikacang panjang, dimana hasil penelitian Hamidah (2014) menunjukkan bahwa penurunan 
pendapatan sebesar $10 \%$ dengan biaya produksi tetap, usaha tani kacang panjang masih layak untuk dikembangkan baik dari aspek NPV, Net B/C maupun dari aspek Gross B/C.

\section{Skenario Ketiga (Manfaat Turun $\mathbf{1 0 \%}$ dan Biaya Naik $\mathbf{1 0 \% )}$}

Akibat adanya penurunan nilai manfaat/penerimaan sebesar $10 \%$ dan biaya naik $10 \%$, maka pada padausahatani padi organik di Kabpaten Buton Utara akan menyebabkan kenaikan rata-rata biaya produksi dan penurunan rata-rata manfaat/penerimaan sebagai berikut:

- Penurunan manfaat sebesar $10 \%$ pada usahatani padi organik di Kabupaten Buton Utara, akan menyebabkan penurunan rata-rata manfaat atau penerimaaan dari $\mathrm{Rp} 25.287 .500$,- menjadi Rp 22.758.750,- per hektar per tahun.

- Kenaikan harga sebesar $10 \%$ maka menyebabkan kenaikan rata-rata biaya investasi sebesar Rp 13.832.500,- pada tahun awal usaha.

- Khusus pada tahun ke-4 terjadi penambahan biaya Rp 5.126.000,-, dimana pada tahun ini terdapat penambahan biaya pagar, jaring/waring, dan biaya pondok jaga. Hal ini disebabkan karena umur ekonomis barang tersebut selama 4 (empat) tahun.

Berdasarkan perubahan-perubahan tersebut, maka hasil analisis sensitivitas usahatani padi organik, dengan skenario ketiga dapat dilihat pada Tabel 8.

Tabel 8. Analisis ekonomi dan finansial usahatani padi organik dengan manfaat turun $10 \%$ dan biaya naik $10 \%$

\begin{tabular}{cccc}
\hline $\begin{array}{c}\text { Indikator dan Kriteria } \\
\text { Kelayakan }\end{array}$ & $\begin{array}{c}\text { Kelompok Bank } \\
\text { Persero } \\
\text { (df 10,24\%) }\end{array}$ & $\begin{array}{c}\text { Kelompok Bank } \\
\text { Pemerintah Daerah } \\
\text { (df 10,90\%) }\end{array}$ & $\begin{array}{c}\text { Kelompok Bank } \\
\text { Swasa Nasional } \\
\text { (df 10,77\%) }\end{array}$ \\
\hline NPV (Layak) & 2.432 .628 & 1.989 .832 & 2.229 .509 \\
Net B/C (Layak) & 1,17 & 1,14 & 1,16 \\
IRR (Layak) & 17,43 & 17,43 & 17,43 \\
\hline
\end{tabular}

Berdasarkan hasil analisis dari skenario ketiga, diketahui bahwa usahatani padi organik yang dikelola petani juga masih layak untuk diusahakan dan atau dikembangkan, namun memiliki potensi kerugian. Hal ini dapat dilihat dari nilai kriteria investasi yang diperoleh, yakni $N P V>0, N e t B / C>1$, dan $I R R>i$ (tingkat diskonto).Kelayakan usahatani tersebut disebabkan karena manfaat yang diperoleh masih mampu menutupi seluruh kenaikan biaya walaupun terjadi inflasi dan penurunan manfaat. Hasil analisis menunjukkan bahwa pada kelompok bank persero juga mempunyai nilai NVP yang lebih besar dari pada kelompok bank pemerintah daerah ataupun kelompok bank swasta nasional walaupun terjadi penurunan manfaat/penerimaan dan kenaikan biaya sebesar $10 \%$, yaitu sebesar Rp 2.432.628,-. Sementara itu, nilai NPV usahatani padi organik pada kelompok bank pemerintah daerah dan kelompok bank swasta nasional dengan penurunan manfaat/penerimaan dan kenaikan biaya sebesar 10\%, masing-masing sebesar Rp 1.989.832,- dan Rp 2.229.509,-. Tabel 8 juga menunjukkan bahwa pada kelompok bank persero juga mempunyai nilai $N e t B / C$ yang lebih besar dari pada kelompok bank pemerintah daerah ataupun kelompok bank swasta nasional yaitu sebesar 1,17, sedangkan pada kelompok bank pemerintah daerah dan kelompok bank swasta nasional masing-masing sebesar 1,14 dan 1,16. Nilai tersebut memberikan makna bahwa setiap pengeluaran sebesar Rp 1,- akan menyebabkan kenaikan pendapatan bersih sebesar 1,17; 1,14; dan 1,16 kali lipat, sehingga dari aspek nilai Net B/CR usahatanipadi organik di Kabupaten Buton Utara layak untuk dikembangkan.

Selanjutnya, dari perhitungan secara interpolasi dengan penurunan manfaat/penerimaan dan kenaikan biaya sebesar 10\%,, menunjukkan bahwa nilai pada discount factor 10,24\%; 10,90\%; dan $10,77 \%$ pada usahatani padi organik di Kabupaten Buton Utara juga masih layak untuk dikembangkan. Hal ini dapat dilihat dari setiap nilai $I R R$ yang menunjukkan angka yang lebih besar dari tingkat diskonto $(I R R>d f)$, baik tingkat diskonto yang berlaku pada kelompok bank persero, kelompok bank pemerintah daerah, maupun pada kelompok bank swasta nasional yakni sebesar $17,43 \%$. Olehnya itu, dapat disimpulkan bahwa walaupun terjadi penurunan manfaat/penerimaan dan kenaikan biaya sebesar $10 \%$, tidak mempengaruhi keberlangsungan usahatani padi organik.

Potensi kerugian usaha pada skenario ketiga ini dapat terjadi karena 2 (dua) hal. Pertama, jika otoritas moneter dalam hal ini Bank Indonesai (BI) mengeluarkan kebijakan untuk menaikkan tingkat suku bunga riil pada kelompok bank persero, kelompok bank pemerintah daerah, dan kelompok bank swasta nasional. Kedua, jika kenaikan suku bunga (discount factor) yang ditetapkan oleh BI pada masing-masing kelompok bank tersebut sebesar 7,20\%; 6,02\%; dan 6,66\% dari tingkat suku bunga aktual menjadi $17,43 \%$. Kondisi tersebut memberikan makna bahwa jika secara faktual 
nilai tingkat diskonto yang berlaku sebesar 17,43\%, maka usahatanipadi organik di Kabupaten Buton Utara tidak layak untuk diusahakan dan atau dikembangkan. Hal ini disebabkan karena nilai kriteria investasi yang akan diperoleh yaitu $N P V<0, N e t B / C<1$, dan $I R R<i$ (tingkat diskonto).

Berdasarkan ketiga skenario analisis sensitivitas tersebut diketahui bahwa usahatani padi organik dengan kredit investasi pada kelompok bank persero dan kelompok bank swasta nasional lebih layak untuk diusahakan dan dikembangkan. Sementara itu, usahatani padi organik dengan kredit investasi pada kelompok bank pemerintah daerah, rentan terhadap risiko kerugian atau kegagalan usaha, sehingga petani dituntut untuk lebih berani mengambil keputusan dalam hal keberlansungan usahatani pada musim tanam selanjutnya. Hal ini relevan dengan hasil penelitian Suharyanto et al., (2013); Suharyanto et al., (2015) yang menyatakan bahwa kelayakan ekonomi pada usahatani sangat erat kaitannya dengan ketepatan manajemen dalam pengambilan keputusan. Semakin tepat keputusan yang diambil oleh petani, maka akan meningkatkan kelayakan ekonomi pada usahatani tersebut (Prihtanti, 2016; Bola \& Prihtanti, 2019; Kaparang, 2015).

\section{KESIMPULAN DAN SARAN}

ekonomi dan finansial usahatani padi organik di Kabupaten Buton Utara berdasarkan kriteria net present value, net benefit cost ratio dan internal rate of return layak untuk diusahakan dan atau dikembangkan. Usahatani padi organik berdasarkan analisis sensitivitas menunjukkan bahwa walaupun terjadi perubahan harga input, usahatani padi organik di Kabupaten Buton Utara tetap layak untuk diusahakan dan atau dikembangkan. Selain itu, pemilihan kredit investasi usahatani pada kelompok bank persero dan kelompok bank swasta nasional lebih layak untuk diusahakan, sedangkan kredit investasi usahatani pada kelompok bank pemerintah daerah rentan terhadap risiko kerugian. Olehnya itu dalam pengajuan kredit investasi usahatani padi organik, petani harus memilih lembaga keuangan pada kelompok bank persero atau bank swasta nasional.

\section{UCAPAN TERIMAKASIH}

Tim penulis mengucapkan terimakasih kepada Pemerintah Daerah Kabupaten Buton Utara, atas kepercayaannya dalam mendanai pelaksanaan riset ini. Penelitian ini terlaksana atas kerjasama Pemerintah Daerah Kabupaten Buton Utara dengan Lembaga Penelitian dan Pengabdian Kepada Masyarakat Universitas Halu Oleo Kendari. Penulis juga tidak lupa mengucapkan penghargaan yang setinggi-tinggi kepada seluruh masyarakat Buton Utara, terutama para petani padi organik (padi ladang) atas segala waktu dan informasinya selama kegiatan penelitian berlangsung.

\section{REFERENSI}

Abdi. (2014). Deforestasi, kelayakan usahatani dan partisipasi petani dalam konservasi lingkungan kawasan hutan di Sulawesi Tenggara. Disertasi. Program Pascasarjana Universitas Gadjah Mada. Yogyakarta.

Aminah, S. (2017). Analisis potensi pengembangan pertanian organik dalam upaya peningkatan pendapatan petani (studi kasus pertanian rakyat di Kecamatan Maro Sebo Kabupaten Muaro Jambi). J-MAS Jurnal Manajemen dan Sains, 2(1), 1-10. https://doi.org/10.33087/jmas.v2i1.9

Bola, E., \& Prihtanti, T. M. (2019). Perilaku petani padi organik terhadap risiko di Kecamatan Susukan Kabupaten Semarang. SOCA Jurnal Sosial Ekonomi Pertanian, 13(2), 280-290. https://doi.org/10.24843/soca.2019.v13.i02.p10

BPS.(2018.a). Kabupaten Buton Utara dalam angka. Badan Pusat Statistik Buton Utara. Buranga.

BPS.(2018.b). Suku bunga kredit rupiah menurut kelompok bank tahun 2002-2018. Badan Pusat Statistik RI. Jakarta.

Fadlun, Muis, A., \& Sulaeman. (2017). Analisis kelayakan finansial usahatani jagung di Sumari Kecamatan Sindue Kabupaten Donggala. e-J. Agrotekbis, 5(3), 357-362.

Hamidah, E. (2014). Analisis kelayakan dan sensitivitas usahatani kacang panjang varietas zebra (Vignasinensil. L) (Studi kasus di Desa Pilanggot Kecamatan Tikung Kabupaten Lamongan). Saintis, 6(1), 57-72.

Hamzah, A., Abdi, Gafaruddin, A. \& Mukhtar. (2018). Laporan akhir analisis kelayakan ekonomi dan finansial pengembangan padi organik di Kabupaten Buton Utara. Kerjasama Bappeda Kabupaten Buton Utara dengan LPPM UHO Kendari. Kendari.

Hamzah, A., Limi, M. A., Mukhtar, Jabudin, L. O., \& Abdi. (2019). The potential of organic rice commodities in North Buton Regency. International Journal of Scientific and Technology Research, 8(12), 671-673. 
Herawati, N. (2015). Pengembangan pariwisata berkelanjutan berbasis Subak sebagai bagian warisan budaya dunia Unesco di Desa Mengesta Kabupaten Tabanan. JUMPA Jurnal Master Pariwisata, 2(1), 79-103. https://doi.org/10.24843/jumpa.2015.v02.i01.p05

Jamil, A.S., Saleh, I., Sungkawa, I., \& Mardhatilla, F. (2018). Analisis perbandingan kelayakan usahatani padi organik dan konvensional (studi kasus: Kecamatan Cigugur Kabupaten Kuningan Jawa Barat), Tema: Pembangunan Pertanian Berkelanjutan Berbasis Sumberdaya Lokal. Prosiding Seminar Nasional Fakultas Pertanian Universitas Jambi tahun 2018, (pp.530-539)

Kaparang, G. (2015). Kajian usahatani padi sawah di Kelurahan Taratara Satu Kota Tomohon. Jurnal Cocos, 6(6), 1-12.

Krisdianto, Lestari, R.E., \& Sutrisno, J. (2014). Analisis kelayakan usahatani padi organik di Komunitas Ngawi Organik Center (KNOC) Kabupaten Ngawi. Program Studi Agribisnis Universitas Sebelas Maret Surakarta. Solo.

Kurniawan, D. (2016). Prospek pengembangan agribisnis padi organik di Kabupaten Kediri guna mendukung program ketahanan pangan di Jawa Timur. Jurnal IImiah Inovasi, 1(1), 23-32. https://doi.org/10.25047/jii.v16i1.4

Listiana, I., Sadono, D., \& Tjiptopranoto, P. (2018). Hubungan kapasitas penyuluh dengan kepuasan petani dalam kegiatan penyuluhan. Jurnal Penyuluhan, 14(2), 244-256. https://doi.org/10.25015/penyuluhan.v14i2.18673

Machmuddin, N., Kusnadi, N., \& Syaukat, Y. (2017). Analisis efisiensi ekonomi usahatani padi organik dan konvensional di Kabupaten Tasikmalaya. Forum Agribisnis (Agribusiness Forum), 6(2), 145-160. https://doi.org/10.29244/fagb.6.2.145-160

Mamondol, M.R. (2016). Analisis kelayakan usahatani padi sawah di Kecamatan Pamona Puselemba. Jurnal Envira, 2(1), 1-9.

Mayrowani, H. (2016). Pengembangan pertanian organik di Indonesia. Forum Penelitian Agro Ekonomi, 30(2), 91-108. https://doi.org/10.21082/fae.v30n2.2012.91-108

Neliyana, Wiryawan, B., Wiyono, E. S., \& Nurani, T. W. (2016). Analisis kelayakan usaha perikanan pukat cincin di pelabuhan perikanan pantai (PPP) Lampulo Banda Aceh Propinsi Aceh. Journal of Marine Fisheries Technology and Management, 5(2), 163-169. https://doi.org/10.29244/jmf.5.2.163-169

Nurjayanti, A., Effendi, I., \& Nurmayasari, I. (2016). Pendapatan dan manfaat usahatani padi organik di Kabupaten Pringsewu. JIIA, 4(2), 126-133. http://dx.doi.org/10.23960/jiia.v4i2.\%25p

Padangaran, A.M. (2013). Analisis kuantitatif pembiayaan perusahaan pertanian. IPB Press. Bogor.

Prihtanti, T. M. (2016). Analisis risiko berbagai luas pengusahaan lahan pada usahatani padi organik dan konvensional. Jurnal Agric., 26(1), 29-36. https://doi.org/10.24246/agric.2014.v26.i1.p2936

Rianse, U., \& Abdi. (2008). Metodelogi penelitian sosial dan ekonomi: teori dan aplikasi. Alfabeta. Bandung.

Rahayu, M. D., \& Yuliawati. (2020). Pendapatan dan risiko usahatani padi organik dan non organik di Karangasem, Ketapang, Susukan, Kabupaten Semarang. Ziraa'ah, 45(1), 45-53. https://doi.org/10.1017/CBO9781107415324.004

Rusastra, I. W., Sumaryanto, N., \& Simatupang, P. (2016). Agricultural development policy strategies for Indonesia: Enhancing the contribution of agriculture to poverty reduction and food security. Forum Penelitian Agro Ekonomi, 23(2), 84-101. https://doi.org/10.21082/fae.v23n2.2005.84101

Sahara, D., Alam, N., \& Idris. (2007). Analisis titik impas dan sensitivitas terhadap kelayakan finansial usahatani padi sawah. Jurnal Pengkajian dan Pengembanagan Teknologi Pertanian, 10(2), 118-124.

Sari, L. R., \& Fahmi, A.. (2018). Dampak subsidi pupuk terhadap peningkatan pendapatan dan kesejahteraan petani Kecamatan Megaluh Jombang dalam perspektif fenomenologis (studi kasus Dusun Sudimoro dan Dusun Paritan). MARGIN ECO: Jurnal Bisnis Dan Perkembangan Bisnis.

Sari, P. N., Hilmi, Y. S., \& Hariswanti, W. S. (2019). Kelayakan dan nilai tukar petani padi organik di Kabupaten Sleman. Jurnal Sosial Ekonomi dan Kebijakan Pertanian, 7(2), 120-128. https://doi.org/10.21107/agriekonomika.v7i2.3928

Sgroi, F., Candela, M., Di Trapani, A. M., Foderà, M., Squatrito, R., Testa, R., \& Tudisca, S. (2015). Economic and financial comparison between organic and conventional farming in Sicilian lemon orchards. Sustainability (Switzerland), 7, 947-961. https://doi.org/10.3390/su7010947

Sugiyono. (2012). Metode penelitian administrasi dilengkapi dengan metode R\&D. Alfabeta. Bandung. https://doi.org/10.1007/s11116-011-9347-8 
Suharyanto, Mulyo, J. H., Darwanto, D. H., \& Widodo, S. (2013). Analisis efisiensi teknis pengelolaan tanaman terpadu (PTT) padi sawah di Provinsi Bali. Jurnal SEPA, 11(13), 45-55.

Suharyanto, S., Mulyo, J. H., Darwanto, D. H., \& Widodo, S. (2015). Analisis Produksi dan Efisiensi Pengelolaan Tanaman Terpadu Padi Sawah di Provinsi Bali. Jurnal Penelitian Pertanian Tanaman Pangan, 34(2), 131-143. https://doi.org/10.21082/jpptp.v34n2.2015.p131-143

Suswadi. (2018). Analisa Karakteristik dan Tingkat Efisiensi Pada Pengembangan Usaha Tani Padi Organik (Oryza Sativa, L.) Di Kabupaten Boyolali. Prosiding Seminar Nasional.

Tudisca, S., Di Trapani, A. M., Sgroi, F., \& Testa, R. (2014). Organic farming and economic sustainability: The case of Sicilian durum wheat. Quality- Access to Success, 15(138), 93-96. https://www.researchgate.net/publication/278390916.

Yasa., I. N. A., \& Handayani. (2017). Analisis produksi dan pendapatan usahatani padi sawah di Desa Bonemarawa Kecamatan Riopakava Kabupaten Donggala. Jurnal Agrotekbis. 5(1), 111-118. 